\title{
Challenges of metal recycling and an international covenant as possible instrument of a globally extended producer responsibility
}

\author{
Hennning Wilts, Stefan Bringezu, Raimund Bleischwitz, \\ Rainer Lucas and Dominic Wittmer
}

\begin{abstract}
As illustrated by the case studies of end-of-life vehicles and waste electric and electronic equipment, the approach of an extended producer responsibility is undermined by the exports of used and waste products. This fact causes severe deficits regarding circular flows, especially of critical raw materials such as platinum group metals. With regard to global recycling there seems to be a responsibility gap which leads somehow to open ends of waste flows and a loss or down-cycling of potential secondary resources. Existing product-orientated extended producer responsibility (EPR) approaches with massbased recycling quotas do not create adequate incentives to supply waste materials containing precious metals to a highquality recycling and should be amended by aspects of a material stewardship. The paper analyses incentive effects on EPR for the mentioned product groups and metals, resulting from existing regulations in Germany. It develops a proposal for an international covenant on metal recycling as a policy instrument for a governance-oriented framework to initiate systemic innovations along the complete value chain taking into account product group- and resource group-specific aspects on different spatial levels. It aims at the effective implementation of a central idea of EPR, the transition of a waste regime still focusing on safe disposal towards a sustainable management of resources for the complete lifecycle of products.
\end{abstract}

\section{Keywords}

Extended producer responsibility (EPR), platinum group metals (PGM), waste shipments, end-of-life vehicles (ELV), waste electric and electronic equipment (WEEE), redistribution, covenant

Date received: 28 February 2011; accepted: 5 June 2011

\section{Introduction}

Approaches concerning extended producer responsibility (EPR) have raised high expectations regarding an evolution of the present waste management from being mainly focused on safe disposal towards recycling and resource conservation and thus contributing to an integrated product policy (OECD, 2004). However, for the key products, namely vehicles and electronic devices, the expected innovatory effects on the management of material flows associated with these productshave largely failed. The starting point of the present paper is to broaden the instrument of EPR to aspects of a global material responsibility from the perspective of a sustainable resource management (SRM). Therefore in the next section the aspiration and reality of EPR are compared regarding different product groups using the example of platinum group metals (PGM). The following section derives the limits of the existing EPR approaches and develops a governance-oriented proposal for an instrumental implementation aiming at systemic innovations and in the final section some preliminary conclusions are drawn.

\section{Sustainable resource management and worldwide recovery of PGM}

Any socio-economic system and any entrepreneurial activity are based on the use of natural resources. Given the finite resources and limited carrying capacities of ecosystems and

Wuppertal Institute, Research Group Material Flows and Resource Management, Wuppertal, Germany.

\section{Corresponding author:}

Hennning Wilts, Wuppertal Institute, Research Group Material Flows and Resource Management, Döppersberg 19, 42103 Wuppertal, Germany

Email: henningwidawupperinst.org 
facing the complexity of the relationship between the environmental and the socio-industrial metabolism, the decoupling of resource use and economic performance has become a widely accepted goal (Bringezu, 2011). For this purpose, the right balance between dematerialization and re-materialization needs to be found. This article deals with the second strategy, to forward recycling throughout various scales. The use of non-renewable resources such as metals is one of the key challenges of sustainable resource management (Giljum et al., 2008): metals and the ecological rucksacks associated with their production (from mining to processing) are one of the three main drivers of the global total material requirement (Bringezu and Bleischwitz, 2009). Also from an economic point of view a more efficient use of metal resources is one of the crucial future tasks.

For industry, higher material and energy efficiency is a chance to reduce costs and enhance competitiveness. The search for eco-efficient technologies is thought to trigger sustainable innovation (Bleischwitz, 2010).

Companies depend on a secure raw material supply. Germany and the European Union (EU) as regions that are poor in ores are highly dependent on imports of ores and metals: There is a significant increase in global metal demand, especially from countries such as China and India.

Although waste regulations have so far mainly focused on the optimization of recycling of mass flows, so-called critical metals have also been attracting interest lately. They are critical insofar as they have low reserve-to-production ratios, high growth rates of demand are expected due to market penetration of new technologies, and economic incentives have not yet been sufficient for the development of appropriate recycling infrastructures. Some metals also show structural shortages as their extraction as by-products is linked to mass metals, so that even significantly increasing prices of the by-products will only lead to a slightly increased production (Buchert et al., 2009). In addition, changes in the geopolitical-economic framework can impact on the supply side which is often characterized by a high level of concentration of the production processes in a few countries. Thus many emerging economies pursue industrial development strategies by means of trade, taxation and investment instruments for critical metals in order to reserve their resource base for their exclusive use (Commission of the European Communities, 2010).

As these rare metals have received less attention in the technical literature than ferrous and base metals, the availability of knowledge is also relatively limited regarding material losses along their life cycles and only recently have these knowledge gaps been addressed by distinct studies, for example regarding the environmental relevance of rare metals (Wittmer et al., 2009). In the following, structures and causes of the continuing failure to especially recycle consumer goods will be discussed taking the example of PGM. Technically, a high-grade PGM recycling is not a challenge:
For industrial applications, taking for example industry catalysts, recycling rates of more than $90 \%$ are achieved (Saurat and Bringezu, 2008). In contrast, the recycling rates of consumer goods are significantly lower. For example, the portion of recycling for the supply of PGM in automobile catalysts was only about $26 \%$ in 2010 (JM, 2010; p. 36). PGM has been identified as one of 14 critical raw materials by the EU Raw Materials Initiative (Commission of the European Communities, 2010). Table 1 shows the theoretical potential to increase resource productivity which is wasted by missing circular flows: primary production of platinum causes about 78 times more total material requirements (TMR) than secondary production.

A fundamental problem for the recycling of PGM are exports of used and waste products into regions where either no recycling infrastructure is available at all or it only exists in the form of "backyard recycling" with low recovery rates and severe risks for health and environment (Hagelüken and Buchert, 2010). Taking the example of three of the most important application fields for PGM in Germany (catalytic converters, mobile phones and screens), in a first step the relevance of these exports are described and the resulting PGM losses are estimated before the relationship between these losses and existing EPR schemes is analysed in the second step.

Given severe problems with the availability of data - especially regarding exports of used products and qualitative aspects of recycling determining the recovery rates for precious metals - the following case studies are based on a review of the few existing studies on this topic, analysis of sector-specific market developments and export statistics as well as on several expert interviews mainly in order to assess the reliability of different sources for information. Altogether the lack of consistent knowledge about these material flows can be regarded as a major barrier for a sustainable resource management.

\section{Case study: catalytic converters}

In 2008 only $15 \%$ of a total of 3 million deregistered cars were supplied to waste treatment in Germany. Evaluations of EU databases for the re-registration of vehicles show

Table 1. Comparison of environmental pressures associated with PGM in 2005

\begin{tabular}{ll}
\hline Pressure indicator & Platinum \\
Primary production, TMR in t/t & 683565 \\
Secondary production, TMR in $\mathrm{t} / \mathrm{t}$ & 8739 \\
Primary production, $\mathrm{CO}_{2} \mathrm{eq}$ in $\mathrm{t} / \mathrm{t}$ & 39839 \\
Secondary production, $\mathrm{CO}_{2}$ eq in $\mathrm{t} / \mathrm{t}$ & 2875 \\
\hline
\end{tabular}

Source: Saurat and Bringezu (2008). 


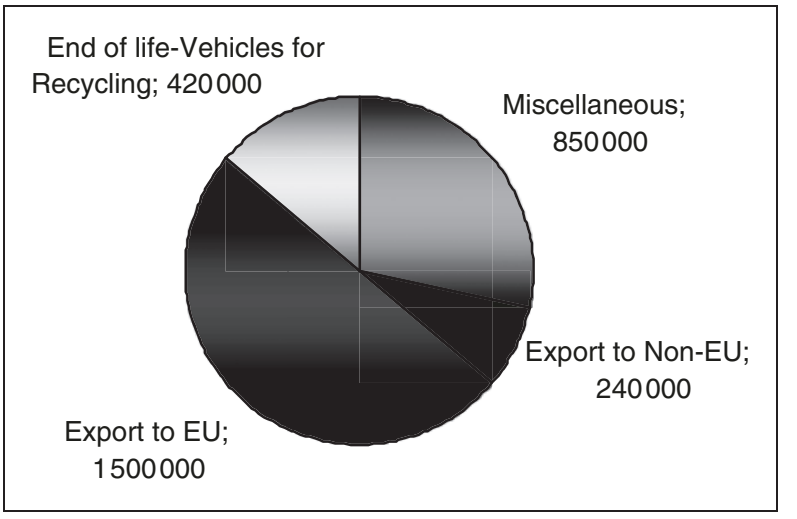

Figure 1. Destination of the deregistered cars in Germany in 2008 (numbers rounded) Source: BMU/UBA (2010).

Table 2. Important non-EU destination countries for used cars out of the 27 European Union member states in 2009

\begin{tabular}{ll}
\hline Destination & Quantity \\
\hline Belarus & 105902 \\
Benin & 73528 \\
Kazakhstan & 64930 \\
Angola & 49129 \\
Nigeria & 38420 \\
Serbia & 33585 \\
Bosnia and Herzegovina & 27264 \\
Norway & 25170 \\
Turkmenistan & 23814 \\
Tajikistan & 22150 \\
Cameroon & 20983 \\
Ghana & 16356 \\
\hline
\end{tabular}

Table 3. Losses in the recycling of PGMs in discarded mobile phones in 2009

\begin{tabular}{lll}
\hline Life cycle stages & Quantity & PGM \\
\hline Input: sold mobile phones & ca. 27 million & $243 \mathrm{~kg}$ \\
Discarded mobile phones & ca. 21.6 million & $194.4 \mathrm{~kg}$ \\
$\quad$ Netto remaining in households & ca. 0.6 million & $5.4 \mathrm{~kg}$ \\
Separately collected for recycling & ca. 3 million & $27 \mathrm{~kg}$ \\
Separately collected for reuse & ca. 1 million & $9 \mathrm{~kg}$ \\
Disposed into residual waste & ca. 4 million & $36 \mathrm{~kg}$ \\
Losses due to domestic treatment & & $10.53 \mathrm{~kg}$ \\
Export & ca. 13 million & $117 \mathrm{~kg}$ \\
\hline
\end{tabular}

that $50 \%$ of the cars have been exported as used cars to other EU-countries (mainly the new member states; BMU/UBA 2010). The following illustration shows an update of the export statistics (Figure 1).

Based on the analysis of expert interviews and project workshops, it can be concluded that a significant share of the German intra-EU exports are shipped to non-EU countries without extensive end-of-life vehicle (ELV) recycling.
Table 2 shows the main destinations for used car exports, primarily the former Soviet republics countries and West Africa (in recent years Russia has also been a major importing country, but nowadays, it increasingly establishes import restrictions on used vehicles in order to protect domestic production).

These exports cause losses of about 1.6t PGM for highquality recycling within the ELV regime (Eurostat (2011)). However, based on various Eastern European country studies, it can be stated that especially catalytic converters used in highquality vehicles with correspondingly high PGM content are recycled in these countries, but often by hydro-chemical methods with significantly lower recovery rates. Afterwards these amounts often flow back in the PGM market through grey markets (Lucas and Wilts, 2011).

\section{Case study: mobile phones}

In 2009 approximately 26.9 million mobile phones were sold in Germany (Bitkom, 2010). With an average PGM content of $9 \mathrm{mg}$ per device (Hagelüken, 2010) this corresponds to an annual PGM demand of approximately $243 \mathrm{~kg}$. From the development of penetration rates in German households it can be concluded that about $80 \%$ of these devices replace an old one. A total of 120 million units are stored as hibernating stocks in German drawers and are thus (at the moment) not available for recycling.

Based on figures for the weight-related composition of mixed collection groups published by the German foundation 'elektro-altgeräte-register' (register for waste electronic products - ear Stiftung Elektroaltgeräteregister) and an average weight for mobile phones of $197 \mathrm{~g}$ it can be concluded that in 2009 about 2.5 million mobile phones were collected within the redistribution systems in the waste electric and electronic equipment (WEEE) regime (ear Stiftung Elektroaltgeräteregister, 2011). In addition, about 1.5 million devices have been collected by professional recyclers, manufacturers and charitable organizations. About 4 million devices per year are disposed of as household waste so that most of the precious metals they contain are lost (Chancerel and Rotter, 2009). Regarding exports the analysis of German foreign trade statistics shows that about 13 million of the remaining units are exported into non-EU countries (Table 3). Assuming that at least $80 \%$ of these devices are not recycled in a high-quality way, in 2009 these exports resulted in a loss of PGM of approximately $117 \mathrm{~kg}$.

\section{Case study: screens}

Unit sales of screens have increased dramatically on a global scale in the last 10 years. Therefore, two particular key drivers can be identified: On the one hand the growing configuration of households with computers, on the other the replacement of the old cathode ray tube (CRT) devices by 
flat screens. The total annual demand for PGM in Germany for screens can be estimated at about $360 \mathrm{~kg}$, based on data on PGM contents per unit (Chancerel, 2010; p. 154) and sales figures. In 2009 of the total 18 million screens sold (including notebooks), 1\% was allocated to CRT television (TV), 46\% to flat panel displays (LCD and plasma) and 53\% to LCD computer monitors (LCD monitors and notebook displays) (GFU, 2009).

Taking into account expert assessments and data on the equipment of household configuration with screens, it can be concluded that every year about 7.6 million computer monitors and 7.6 million TV sets are discarded. Based on evaluations of the composition of the relevant collection groups (ear Stiftung Elektroaltgeräteregister, 2011), about $130000 \mathrm{t}$ of screens have been collected within the EAR system in 2009. Assuming an average weight of about $5 \mathrm{~kg}$ for computer monitors and $12 \mathrm{~kg}$ for televisions sets, this would correspond to around 10 million data terminals and 6.5 million TVs in 2009. The predominantly illegal export of screen equipment can only be estimated with much uncertainty. Based on current studies by Sander and Schilling (2010) and Janz et al. (2009), an annual export of about 3-5 million units can be supposed. According to the assumptions made regarding PGM contents in CRT and flat screen, this would mean a loss of about $70 \mathrm{~kg}$ PGM per annum (Table 4).

\section{Potentials of a global EPR}

Extended producer responsibility is one of the key approaches of waste legislation, which could contribute to sustainable resource management enabling the preservation of resources and furtherance of a 'recycling society' (Commission of the European Communities, 2011). There is no uniform definition of what is meant by EPR. The OECD (2004) has worded it in a very general way as follows: 'an environmental policy approach in which a producer's responsibility, of both, physical and/or financial nature, for a product is extended to the post-consumer stage of a product's life cycle'. There is an extensive debate about its concrete specification (e.g. individual vs. collective concepts, cf.

Table 4. Losses for recycling of PGMs in discarded screens in 2009

\begin{tabular}{|c|c|c|}
\hline Life cycle stages & Quantity & PGM \\
\hline Input: screens sold & ca. 18 million & $355 \mathrm{~kg}$ \\
\hline \multicolumn{3}{|l|}{ Discarded screens } \\
\hline TV sets & ca. 7.6 million & $135 \mathrm{~kg}$ \\
\hline Computer monitors & ca. 7.6 million & $127.5 \mathrm{~kg}$ \\
\hline Collected for recycling & ca. 15.2 million & $262.5 \mathrm{~kg}$ \\
\hline $\begin{array}{l}\text { Losses due to domestic } \\
\text { treatment }\end{array}$ & & $139.2 \mathrm{~kg}$ \\
\hline Exports & ca. 3-5 million & $52.5-87.5 \mathrm{~kg}$ \\
\hline
\end{tabular}

Van Rossem, 2009) aiming at the implementation of this very broad concept. This paper tries to analyse specific incentive structures caused by European EPR concepts for end-of-life vehicles as well as for electronic waste implemented in Germany by the laws on WEEE (ElektroG) and ELVs (AltautoV). Complementary to mandatory take-back obligations and related financial responsibility of the producer, the promotion of commodity circulation shall be supported or forced by mandatory recovery rates (Beyer and Kopytziok, 2005; p. 20):

According to the ElektroG since $20064 \mathrm{~kg}$ per capita of WEEE have to be collected and recovered, for IT equipment and consumer electronics the recovery rate has to amount to at least $75 \%$ (at least $65 \%$ re-use and recycling). The collection costs have to be born by the local authorities in Germany, the producers have to take the responsibility for the recycling.

According to the AltautoV for end-of-life vehicles the producers have to enable a free return for the last owner of a car. During initial treatment, removal of the catalytic converters is required and a total of at least $80 \%$ of the average vehicle weight ( $85 \%$ from 2015 ) has to be recycled.

\section{Limitations of existing EPR approaches}

Against the background of these case studies the different conceptual gaps of existing EPR schemes are now analyzed, taking into account the collection and recycling of used products.

Objective differentiation: In contrast to most environmental regulations, EPR approaches refer to a concrete product, not to the actual production process or to the resulting waste. The ecological rucksacks associated with the different products usually comprises a multiple volume of the actual product but remain hidden from the very beginning. As a reference point for the producer's responsibility only the product itself remains and its configuration and composition shall be influenced in terms of eco-friendly design. Given the increasing complexity of products and the variety of production steps and materials used, the question arises who actually would take responsibility for the fate of these substances. As there is and will be no single person or institution who owns processes and produces throughout the whole cycle of extraction, production, consumption, recycling, and disposal, the question is how responsibility for a systems-wide sustainable management can be attributed to the actors along the chain in a way that favours sustainable management of the substances involved. With regard to global redistribution systems and recycling there seems to be a 'responsibility gap', which leads somehow to open ends of waste flows and a loss or down-cycling of potential secondary resources.

For the mass-based collection targets, the tiny amounts of precious metals in small electrical appliances or the catalytic 
converters are not a relevant issue (Chancerel 2010). Referrence to the high mass-based recycling targets, its environmental compliance costs and other relevant costs (e.g. labour costs) lead to high costs for the entire system which average out at about 5.6 billion euros for the collection and recycling of WEEE (Commission of the European Communities, 2008). These costs, as well as the high global demand for used products have created incentives for legal second-hand goods exports, grey markets and illegal waste shipments. From the perspective of sustainable resource management, it will be necessary to augment EPR to aspects of material stewardship, not only including the directly controllable aspects of the production process, but also taking responsibility for the materials used in their useful and endof-life phases (OECD, 2010; p. 15). The mere obligation to take back a product does not determine a recycling of the materials contained. Even mandatory recycling rates usually refer to the total weight of a product and thus provide no incentives for the recovery of precious metals. The producer will always select the cheapest disposal according to economic criteria (Beyer and Kopytziok, 2005). Even if products in principle could be recovered profitably, transaction costs lead to a preference for primary raw materials, due to the spatially and temporally distributed generation of secondary raw materials. Also the European Commission demands in its 'Thematic Strategy on Waste Prevention and Recycling' (Commission of the European Communities, 2005; p. 20) a more material specific concept of producer responsibility.

Spatial differentiation: As an approach of direct control based on regulatory law, EPR is limited to a German or at least European regulatory space. At the same time, however, it can be observed that material and waste streams are increasingly globalized. The analysis of the physical material flows shows that in the course of globalization the EU has increasingly replaced domestic resource extraction by the import of products or semi-finished products, which has led to a reduction of the local environment burden and added additional damage especially to developing and emerging countries (Bringezu and Bleischwitz, 2009; p. 59). At the same time, used and waste products are still exported (illegally, as well as legally as used products) from Europe into developing and emerging countries. Analysing the incentive structures established by the WEEE and the ELV directive, it is obvious that the existing institutional framework is not suitable to promote the circulation of PGM for a highquality recycling. Without ambitious collection targets it instead provides additional incentives for export and thus promotes PGM losses (de Bruijn and Norberg-Bohm, 2005). One reason for this development is the increasingly stringent European environmental standards in the waste legislation reducing the environmental pressures in Europe on the one hand, and, on the other hand, leading to a burden shifting into emerging and developing countries: for example, the prescribed removal standards in the ELV or WEEE directives lead to significant incidental costs, so that it is often cheaper to export products to Asia or Africa and dispose of them there. For ELV, the removal of pollutants and dangerous parts like air bags costs about 260 euros (cf. UBA, 2002). For screens, investigations have shown that the proper treatment in Germany costs about 4 euros per monitor; by contrast the export to Africa and dumping there only costs about 1.50 euro (Hagelüken, 2007).

The case studies show that from the perspective of sustainable resource management, the national environmental policies are increasingly limited. A correspondence between spatial extent of the material flows and the 'manageable space' as a prerequisite for efficient regulation is more and more missing. In order to actually set effective incentives for resource conservation and recycling of raw materials by EPR, the manufacturers' responsibility can not be allowed to end at the border. This will require new governance approaches beyond regulatory law, which also have to involve stakeholders in the destination countries of the exports.

Differentiation of actor orientation: Generally, the producer is responsible in terms of EPR. The wording suggests that this is the person or institution who actually manufactures products. In fact, the circle of addressees goes far beyond the actual manufacturer. For example, the ELV defines the concept of 'economic operators', which includes producers, distributors, collectors, motor vehicle insurance companies, dismantlers and companies for shredding, recovery, and recycling of ELV. Furthermore, the member states must also ensure that vehicles placed on the market are free of certain pollutants (Article 2, Nr. 10). Lauridsen and Jorgensen (2010) point out that an EPR which is only manufacturer-oriented pursues a too mono-causal explanation approach for innovation. Nowadays, many products are developed in modular networks, each with very different standards and governance structures. If EPR aims not only at incremental innovations for individual production steps but at systemic innovations along the complete value-chain, many other additional stakeholders will have to be involved. This has to take into account that neither a common understanding of the problem, nor a common interest in problem solving can be assumed automatically.

\section{International covenants as a possible solution approach}

In the following, based on the deficits observed and the limits of direct regulation regarding the recycling of exported products within the ambit of EPR schemes, a so called covenant is outlined to enhance material efficiency and resource conservation in this field of action. The covenant could provide a framework to close material flows on an international 
level: costs and benefits of increased WEEE or ELV recycling could be distributed more efficiently along the complete value chain. Covenants represent a combination of elements of direct governmental regulation and self-regulation by industry. A draft for such an international instrument has been developed for ELV within the project 'material efficiency and resource conservation' (Wilts et al., 2010). In principle, covenants may be characterized by elements identified in the following list.

Industrial sectors commit themselves to achieving precisely and verifiably defined long-term goals far beyond the expected 'business as usual' scenarios.

These goals are negotiated in co-operation with the responsible authorities of the public sector.

In return, the public authorities commit themselves to omitting further direct regulatory measures for the contract period creating a sufficiently long period warranting stable long-term framework conditions for the enterprises involved to ensure amortization of the necessary investments.

Covenants are concluded as private law contracts between all parties involved. Such contracts include both sanction mechanisms in case the stipulated goals are not achieved, and options to adapt the terms and conditions in case of changing framework conditions.

In the context of this covenant, specific targets should be defined on three levels.

Completion of industrial material cycles: In addition to the targets fixed by the ELV Directive regarding the recycling of a certain share by weight of an ELV, the covenant should define standards that are specific to groups of materials and intermediate targets for the completion of industrial material cycles. These should be based on the quantities currently used, establishing high-quality recycling and recovery procedures. The number of potentially relevant materials includes copper and PGMs because both of these make a decisive contribution to the profitability of ELV recycling. In addition, particular with regard to copper, they require extensive dismantling of the vehicle, thus automatically creating incentives for a sorted recovery of other material groups. In the context of the covenant, industrial partners would commit themselves to recovering a certain (to be negotiated) percentage of metal fractions contained in these vehicles, which would also include the exported vehicles.

Recycling standards: For the recycling industry in the countries of destination, such commitment by the automobile industry would ensure a defined input for treatment facilities in the sector of base metals. Such facilities should be constructed in these countries of destination for the exported vehicles, at least for the first stages of recovery. Regarding the recovery of ELVs, it should be taken into account that although the recycling of materials will lead to considerable resource savings, the treatment procedures proper will be associated with substantial environmental impact potentials, for example if oil and other operating liquids are directly discharged into sewer systems. This is why the recycling industry should be committed to high environmental standards also in the countries of destination, including, for example, compliance with the requirements for treatment facilities according to the ELV Directive (e.g. the removal of operating liquids).

Enhanced monitoring and reporting: Precise and binding reporting obligations for the contracting parties involved should be agreed upon in the covenant. This should, on the one hand, improve information exchange between manufacturers, recyclers and public sector authorities in order to identify possible efficiency potentials and promote innovation processes. On the other, publication of the reports is also intended to exert pressure on individual stakeholders in the case of failure to sufficiently meet their obligations. Relevant national and supranational agencies could and should be included into this process in order to support the provision of policy relevant data; for example, the Environmental Agencies or Data Centres on Waste (Eurostat).

Sanctions: Past experience with regard to covenants has shown a lack of public control and insufficient provisions for discouraging free-rider behaviour of single stakeholders to make up the critical points of the instrument (Bressers et al., 2005). As a matter of principle, a covenant should therefore include options to impose sanctions for non-compliance by means of civil action to enforce contract penalties. In the case of repeated failure to comply with the goals defined, there should be provisions to sanction the contracting parties concerned by means of economic penalties. In the case of manufacturers who fail to meet their obligations, a binding procedure for the settlement of disputes should be introduced. A possible preliminary stage could, for example, consist of the option to exclude enterprises or industries from public research funding. Another measure to be considered could consist of a ban to prevent such enterprises or trade associations from participating in the development of binding standards.

\section{Risks, challenges and necessary}

preconditions: The covenant's approach is based on the existence of sufficient economic incentives for the recycling of such fractions, together with appropriate framework conditions. One should indeed underline a business interest in: (1) getting access to these materials and (2) benefiting from a partnership on the issue. On the other hand, the costs for negotiating and monitoring such an agreement as a substitute for direct regulation should not be underestimated. Of course, the question arises why companies 
should participate voluntarily in the negotiation of such a binding contract which also constitutes a restriction of their entrepreneurial freedom of action. The covenants would have to combine strategic interests on different levels.

The recycling industry has to face the fact that electronic waste and ELV increasingly arise in emerging and developing countries. This is not only caused by exports of used and waste products, but also by an increasing amount of domestic waste generation. For example, for China Yu et al. (2010) estimate that by 2013 more domestic than foreign WEEE will be generated. Therefore, the recycling industry will be substantially interested in establishing redistribution and recycling infrastructures in these countries.

For the manufacturing industry, such a covenant offers the possibility of increasing the security of supply for critical metals by the recycling of ELV or WEEE. The necessity to act is not primarily reasoned by geological scarcity but from structural scarcity; namely here the concentration of primary deposits in specific countries which start increasingly to take advantage of this monopoly situation (for example the case of export controls on rare earth metals in China).

Of course it would be naive to neglect the heterogeneity within the different groups of stakeholders where powerful veto players have strong economic incentives to obstruct such a covenant. For this reason a credible 'shadow of legislation' (Bressers and de Bruijn, 2005; Töller, 2008) by political actors will be crucial to increase the willingness of the parties involved to negotiate and also to put pressure on actors in grey markets. With this in mind developments on the national level of WEEE legislation like in China (cf. Yu et al. 2010) could support the achievement of international agreements like a covenant. Furthermore, established structures such as the Mobile Phone Partnership Initiative under the Basel Convention should be included in the negotiations in order to ensure the practicality of the developed set of rules.

From the authors' point of view, neither too high expectations nor a fundamental scepticism towards covenants would be appropriate. Of course some voluntary environmentally regulations have dramatically failed in the past and therefore the instrument should by no means be considered as an isolated measure but as a part of a comprehensive policy mix to increase resource productivity. Depending on the concrete arrangement, a covenant may have the advantage that all key stakeholders are involved in the negotiation process, which forwards an efficient solution on the one hand, and, on the other hand, may increase the willingness of the parties to actually implement its results.

Covenants as niches for innovation: Nevertheless the covenant bears severe practical, political and legal open questions which have to be balanced carefully against the dynamic effects which could be triggered by such a new arena for innovative solutions (e.g. for the unresolved problems of power and politics in such processes cf. Shove and
Walker (2007)): from a static point of view, direct regulations clearly lead to more predictable results than covenants in order to improve high-quality recycling of PGM (Karup, 2001). Facing the limitations of such instruments, a 'second best-regulation" should particularly consider the innovatory effects of an instrument. Dynamic effects on innovation gain in importance especially in environmental policy. Covenants could represent a form of knowledge-generating institutions (Bleischwitz, 2005), because they lower the transaction costs of information search by sector-wide co-operations and significantly stimulate learning processes in favour of system innovations. The covenant could form a technological niche in terms of a transition management where radical novelties emerge like new business models for the redistribution and recycling of mobile phones or catalytic converters in developing countries.

\section{Conclusions}

As shown, the export of used and waste products into developing and emerging countries without adequate recycling infrastructures is a major cause for the lack of recycling of critical metals. The high export rates thus undermine the basic regulatory EPR approach, the extension of the physical and the financial responsibility on producers to the end-oflife phase of their products. In principle, the EPR aims to set incentives for a recycling-friendly design, if the EOL costs have to be internalized by the producers. These incentives are already significantly weakened by collective collection and financing schemes (Fehling, 2010), but if a relevant share of the products is exported and occurs in developing countries, this approach will be completely foiled.

Therefore, one of the key challenges for metals is to forward recycling also across country borders and enhance a more efficient use along the production chain. Europe looses metals with end-of-life products like scrap cars and WEEE, while the supply of metals is largely based on ores and concentrates imported from abroad. High-level recycling needs to be built up within Europe and beyond that, producer responsibility should be advanced to also establish collection and recovery systems abroad, in co-operation with developing countries as well.

Existing product-orientated EPR approaches focusing on mass-based recycling quota do not create adequate incentives to supply waste materials containing rare metals to highquality recycling and should be amended by aspects of a material stewardship. The large differences between the various product regimes and the resulting different problems point out that for any actor the orientation of the product as a reference needs to remain an important component. In the long term, product group- and resource group-specific elements have to be involved in an overall concept of global resource management: Policies for economy-related sustainable resource management should develop long-term 
objectives for the production and consumption of critical resources. Such concepts have taken into account different spatial levels: Mass metals such as steel or copper can be recycled on a regional level, but especially for precious metals, global redistribution systems have to be developed.

The Raw Materials Initiative of the European Commission underlines the need for bilateral and regional trade agreements in order to secure the access to critical metals for European companies (Commission of the European Communities, 2010; p. 8). This approach should not, as hitherto, be limited to primary deposits, but should increasingly be extended to secondary stocks in future. Therefore, a proposal in the form of the covenant has been developed aiming at systemic innovations through participation of the entire life-cycle chain, but also, at the same time, allocating clear and reliable responsibilities to all parties. A key focus has to be to increase the transparency of material flows. Designing a robust and effective policy framework, key strategies and technologies for sustainable use of natural resources crucially requires improved knowledge on the short- and long-term dynamics of the socio-industrial metabolism.

\section{Acknowledgements}

We also thank two anonymous reviewers for their valuable comments to the manuscript and their constructive suggestions.

\section{Funding}

This work has been developed within the research project 'Material Efficiency and Resource Conservation' (MaRess) funded by the German Environment Ministry and the Federal Environment Agency.

\section{References}

Beyer P and Kopytziok N (2005) Abfallvermeidung und-verwertung durch das Prinzip der Produzentenverantwortung. (Prevention and recovery of waste by the principle of extended producer responsibility). Final Report, Berlin. Forschungsvor- haben für das Österreichische Bundesministerium für Land- und Forstwirtschaft, Umwelt und Wasserwirtschaft. Berlin, Germany.

Bitkom (2010) Handy-Absatz soll 2010 wieder zulegen. (Sales of mobile phones increase in 2010). From Bitkom (2010). Retrieved from http://www.bitkom.org/de/markt_statistik/64086_59451.aspx (accessed 28 February 2011).

Bleischwitz R (2005) Gemeinschaftsgüter durch Wissen generierende Institutionen. Ein evolutorischer Ansatz für die Wirtschaftspolitik. (Public goods by knowledge generating institutions. An evolutionary approach for economic policy). Marburg, Germany.

Bleischwitz R (2010) International economics of resource productivity: Relevance, measurement, empirical trends, innovation, resource policies. International Economics and Economic Policy 7: 227-244.

BMU/UBA (Bundesumweltministerium/Umweltbundesamt) (2010) Altfahrzeug-Verwertungsquoten in Deutschland im Jahr 2008 gemäß Art. 7 Abs. 2 der Altfahrzeug-Richtlinie 2000/53/EG. (ELV recycling quotas in Germany in 2008 due to art. 7 par. 2 ELV Directive 2000/53/ EG). From BMU (2010). Retrieved from http://www.bmu.de/files/ pdfs/allgemein/application/pdf/germany_elv_quota_qualityreport.pdf (accessed 3 December 2010).
Bressers H (2003) The use of covenants in target group policy: Evaluating a Dutch environmental policy innovation, In: 11th International Conference of Greening of Industry Network, October 12-15, 2003, San Francisco, CA. Enschede, The Netherlands: Greening of Industry Network.

Bressers H and De Bruijn T (2005) Conditions for the success of negotiated agreements: Partnerships for environmental improvement in the Netherlands. Business Strategy and the Environment 14: 241-254.

Bringezu S (2011) Key elements for economy-wide sustainable resource management. Responsabilité \& Environment 61: 78-87.

Bringezu S and Bleischwitz R (2009) Sustainable Resource Management: Trends, Visions and Policies for Europe and the World. Sheffield, UK: Greenleaf Publisher.

Buchert M (2010) Recycling, Exportproblematik und Reimportchancen? Werthaltige Komponenten am Beispiel des Katalysators. (Recycling, problems with exports and chances for re-imports? Valuable components taking the example of catalytic converters). In: ThoméKozmiensky KJ and Goldmann D (eds): Recycling und Rohstoffe, vol. 3, Nietwerder, Germany: TK Verlag: 575-584. Berliner Recycling- und Rohstoffkonferenz, May 5, 2010, Berlin, Germany.

Buchert M, Schüler D and Bleher D (2009) Critical Metals for Sustainable Technologies and their Recycling Potential. Bonn, Germany: Report by UNEP/ Öko-Institut.

Chancerel P (2010) Substance flow analysis of the recycling of small waste electrical and electronic equipment. Berlin, Germany: Institut für Technischen Umweltschutz, ITU-Schriftenreihe 09/2010.

Chancerel P and Rotter V (2009) Assessing the management of small WEEE through Substance Flow Analysis - The example of gold in Germany and the USA, In: ISSST 2009, Phoenix, AZ. Washington, DC, USA: IEEE Computer Society's Technical Committee on Sustainable Systems and Technology.

Commission of the European Communities (2005) Taking Sustainable Use of Resources Forward: A Thematic Strategy on the Prevention and Recycling of Waste. COM (2005) 666 final, Brussels, Belgium.

Commission of the European Communities (2008) Commission Staff Working Paper Accompanying the Proposal for a Directive of the European Parliament and of the Council on Waste Electrical and Electronic Equipment-Summary of the Impact Assessment. $\operatorname{COM}(2008) 810$ final, Brussels, Belgium.

Commission of the European Communities (2010) Report of the Ad-hoc Working Group on Defining Critical Raw Materials. From EC (2010). Retrieved from http://ec.europa.eu/enterprise/policies/rawmaterials/files/docs/report_en.pdf (accessed 28 February 2011).

Commission of the European Communities (2011) Report from the Commission on the Thematic Strategy on the Prevention and Recycling of Waste. COM(2011) 0013 final, Brussels, Belgium.

de Bruijn T and Norberg-Bohm V (2005) Industrial Information. Environmental Policy in the United States and Europe. Cambridge, MA: MIT-Press.

ear Stiftung Elektroaltgeräteregister (2011) Zusammensetzung gemischter Sammelgruppen. (Composition of mixed collection groups). From ear (2011). Retrieved from http://www.stiftung-ear.de/aktuell/ aktuelle_mitteilungen/kennzahlen/zusammensetzung_gemischter_ sammelgruppen (accessed 28 February 2011).

Eurostat (2011) Official European Foreign Trade Statistics COMEXT. Eurostat, Luxembourg.

Fehling M (2010) Innovationsförderung durch Herstellerverantwortung und Optionsmodelle im ElektroG. Natur und Recht 32: 323-329.

GFU (Gesellschaft für Unterhaltungs- und Kommunikationselektronik) (2009) Der Markt für Consumer Electronics in Deutschland. From GFU (2011). Retrieved from www.gfu.de/.../de_de_Der $\% 20$ Markt $\%$ 20 für \%20Unterhaltungselektronik\%20-\%20Deutschland \%202009. pdf (accessed 28 February 2011).

Giljum S, Hinterberger F, Biermann B, Wallbaum H, Bleischwitz R, Bringezu S, et al. (2008) Errichtung einer internationalen Datenbank zur Ressourcenintensität von Rohstoffen, Halbwaren und Produkten. (Establishing an international data base for the resource intensivity of raw materials, semi-finished products and final products). Aachen, Germany: Kathy Beys Foundation. 
Hagelüken C (2007) Ressourcenknappheit bei Edelmetallen und seltenen Metallen. (Resource scarcity for precious and rare metals?) Dübendorf, Germany: EMPA Akademie Dübendorf.

Hagelüken C and Buchert M (2010) Kritische Metalle für Zukunftstechnologien und ihr Recyclingpotenzial (Critical metals for future technologies and their recycling potential), In: Materialforum Rhein-Main, 18 January, Hanau, Germany: Materials Valley e.V.

Janz A, Prelle R, Müller F and Bilitewski B (2009) Grenzüberschreitende Ströme von Elektroaltgeräten. (Transboundary flows of waste electronic devices). Müll und Abfall 3: 126-132.

JM (Johnson Matthey) (2010) Platinum 2010. From: JM (2010). Retrieved from www.platinum.matthey.com/publications/marketdata-charts/ (accessed 11 November 2010).

Karup S (2001) Can voluntary approaches ever be efficient? Journal of Cleaner Production 9: 135-144.

Lauridsen EH and Jorgensen U (2010) Sustainable transition of electronic products through waste policy. Research Policy 39: 486-494.

Lucas R and Wilts H (2011) Weltweite Rückgewinnung von PGM. (Global recovery of PGM). Wuppertal, Germany: MaRess-Report Summary.

OECD (Organization for Economic Cooperation and Development: Economic) (2004) Aspects of Extended Producer Responsibility. OECD, Paris, France.

OECD (Organization for Economic Cooperation and Development: Economic) (2010): Policies for Implementing SMM. Summary Paper 3. OECD Environment Directorate, Paris, France.

Sander K and Schilling S (2010) Transboundary shipment of waste electrical and electronic equipment/electronic scrap - Optimization of material flows and control. Dessau, Germany: UBA Texte Nr. 11/2010.
Saurat M and Bringezu S (2008) Platinum group metal flows of Europe, PART I: Global supply, use in industries and the shift of environmental impacts. Journal of Industrial Ecology 5: 754-767.

Shove E and Walker G (2007) CAUTION! Transitions ahead: Politics, practice, and sustainable transition management. Environment and Planning, $H$ 39: 763-770.

Töller AE (2008) Kooperation im Schatten der Hierarchie: Dilemmata des Verhandelns zwischen Staat und Wirtschaft. In: Schuppert GF and Zürn M (eds.) Governance in einer sich wandelnden Welt. Wiesbaden, Germany: PVS-Sonderheft.

UBA (Umweltbundesamt) (2002) Beschreibung des Standes der Technik bei der Vorbehandlung, insbesondere der Trockenlegung von Altautos gemäß AltautoV. FKZ 20033 323, Berlin.

Van Rossem C (2009) Individual producer responsibility - principle vs. practical implementation. From: Conference on Canadian Stewardship (2009). Retrieved from http://www.canadianstewardship.com/2009presdownloads/ 7vanRossemCanadianStewardship.pdf (accessed 26 June 2011).

Wilts H, Bleischwitz R and Sanden J (2010) Ein Covenant zur Schließung internationaler Stoffkreisläufe im Bereich Altautorecycling. (A covenant for closing international material flows in the field of end of life recycling). Resourceneffizienz. Wuppertal, Germany, Paper 3.5.

Wittmer D, Scharp M, Bringezu S, Ritthoff M, Erren M, Lauwigi C, et al. (2009) Metallische Rohstoffe, PGM und Infrastrukturen: Umweltrelevante metallische Rohstoffe. Zwischenbericht zur Phase I: Auswahl von Metallen zur vertiefenden Untersuchung unpublished. (Metallic raw materials, PGM and infrastructures: Environmentally relevant metalic raw materials. Intermediary report phase I: Selection of metals for detailed analysis (unpublished). Wuppertal, Germany.

Yu J, Williams E, Ju M and Yang Y (2010) Forecasting global generation of obsolete personal computers. Environmental Science \& Technology 9: 3232-3237. 